\title{
Design and Development of Customer Satisfaction Couse for Improving Creativity based on CPS Model
}

\author{
Jooyoung $\mathrm{Kim}^{1}$, Yunyoung $\mathrm{Kim}^{2}$, Jaewoo $\mathrm{Do}^{3}$ and Sohyeon $\mathrm{Heo}^{4}$ \\ ${ }^{1}$ Dept. of Educational Technology, Collage of Education, \\ Andong National University, 1375 Kyungdongro, Andong, Korea \\ ${ }^{2}$ Dept. of Educational Technology, Collage of Education, \\ Andong National University, 1375 Kyungdongro, Andong, Korea \\ ${ }^{3}$ Dept. of Educational Psychology \& Counseling, University of Tennessee 535 \\ Jane \& David Bailey Education Complex, 1122 Volunteer Boulevard, Knoxville, \\ Tennessee 37996-3452, United State \\ 4Dept. of Educational Technology, Collage of Education \\ Andong National University, 1375 Kyungdongro, Andong, Koree \\ jooyoung-kim@bpscorp.co.kr,kimyy1001@gmail.com,jdo3@utk.edu, \\ gjth228@gmail.com

\section{Abstract} \\ The talented human resource demanded by companies in the knowledge-based society \\ is the person who has creativity and upright character. Currently, there are 10 basic \\ vocational skills commonly sought in all workers nationwide, and one of them is the \\ problem-solving skills. One of sub-factorn of problemsolving skills is creative thinking. \\ Under these circumstances, various teaching andlearning models have been developed to \\ develop students' creativity and upright character. However, there are not enough \\ discussions on the optimized education prograns. Customer satisfaction (CS) is defined \\ as a condition where customers' needs, desires, and expectations are met or exceeded to \\ result in the repurchase of products andkr services and repeat this to continue customer \\ loyalty. CS skills indude the competencies that promptly adjust to the fast-paced \\ environments and resolve probtems creatively. However, the existing CS training is \\ mainly focused on the attitudes or functions of services, and there is limited effort on \\ developing the abilities toflexibly respond to various real-life issues. Therefore, CS \\ training should be developed in order to improve students' problem-solving skills. \\ Additionally, the scope of CS training is expanding to the broad meaning as training for \\ nurturing the upright character. With social demands for creativity and upright character, \\ the purpose of this study is to develop a CS course that is based on the CPS model to \\ develop college students' creativity and upright character. In this study, researchers \\ developed Creative Problem Solving (CPS) model by adapting and modifying existing \\ CPS model, and developed CS course based on developed CPS model. The significances \\ of developed CS course are as follow: first, it will improve the creativity and upright \\ character of college students who have participated in a CS course that applies the CPS \\ model. Second, it can help professors teaching CS course in colleges teach image-making \\ course based on the CPS model in schools. Third, it is expected to suggest study \\ directions for the development of other CS courses in addition to image-making
}

Keywords: Creative Problem Solving Model, Customer Service, Creativity 


\section{Introduction}

With the rapid development of Korean economies, the talented human resource demanded by companies in the 1990s was those with strong educational backgrounds. However, the society bound to education has caused problems related to lack of human quality and problem-solving skills in the real world [1]. The talented human resource demanded by companies in the knowledge-based society of the 21 st Century is the manpower with creativity and upright character, and these are the qualities sought after in recruitment. Currently, there are 10 basic vocational skills commonly sought in all workers nationwide, and one of them is the problem-solving skills. The subfactors of problem-solving skills valued in the basic vocational skills are the 'thinking skills' related to creative thinking, critical thinking, and logical thinking and 'task-processing skills' related to problem recognition, selection of alternatives, application of alternatives, and assessment of alternatives. Problem-solving needs to generate and select ideas for the best. solution in order to resolve problems in various situations, but creative thinking should be applied in this process [2]. Under these circumstances, various teaching and learning models have been developed in the field of education to develop students' creativity and problem solving skills [3]. However, there are not enough discussions on the development of creativity and upright character [4-5].

CS (Customer Satisfaction) training contributes to develop abilities which everyone should develop with efforts for mutually satisfactory interpersonal relations [6]. CS skills include the competencies that promptly adjust to the fast-paced environments and resolve problems creatively [7]. Thus, CS training program should include contents and methods for comprehensive problem-solving in various situations. However, the existing CS training is mainly focused on the attitudes or functions of services, and there is limited effort on developing the abilities to flexibly respond to various real-life issues [4]. Therefore, CS training should be developed in order to improve students' problemsolving skills for service management, service performance assessment, service leadership, listening attitudes, communication skills, customer complaint handling procedures, MOT management, and inage-making beyond the standardized courtesy training or friendly service training [4,8]. With these demands for CS training, it is necessary to develôp educational programs to improve both problem-solving skills and creativity through CS training for learners.

Creative Problem Solving (CPS) Model is the most popular model for development of creativity. CPS model has been used as the foundation for studies to develop creativity training programs in Korea and abroad [9]. Therefore, this study developed a CS course that applies the CP\$ nodel to develop the creativity and upright character for college students.

\section{Theoretical Background}

\subsection{GS Training and Creativity}

CS is defined as a condition where customers' needs, desires, and expectations are met or exceeded to result in the repurchase of products and/or services and repeat this to continue customer loyalty [10]. The consultative meaning of CS training is to improve the functions of courteous attitudes or services to make interpersonal relationships with others according to the ideologies or purposes of companies. Ultimately, it is to improve the overt attitudes and the technical skills. In the broad meaning for social education, CS training is learning the internal mindset and external courtesies one should make efforts to maintain mutual satisfaction for sound international relationships in the society [11].

CS training in companies has been conducted in consultative meaning with emphasis on the attitudes of employees to reform their awareness and improve their service skills. However, CS training focused on service attitudes or functions is not enough to nurture 
the skills to flexibly respond to various problems that occur in the real world. It requires more multifaceted thinking in order to resolve the problems that occur in the complicated introversion of people [12]. Nowadays, the scope of CS training is expanding to the broad meaning as training for nurturing the upright character all social members should have. It should evolve to have a variety of contents and methods that occurs in the various situations of modern society. For this reason, CS training is evolving to improve various problem-solving skills for service management, service performance assessment, service leadership, listening attitudes, communication skills, customer complaint handling procedures, MOT management, and image-making beyond the standardized courtesy training or friendly service training [13].

Nowadays, colleges are offering CS courses for their students to grow into the images demanded by companies for better competitiveness in the job market. However, the training programs have not deviated from the existing standardized courtesy training. Therefore, it is required to develop alternative programs according to the educational demands for CS training. Above all, the programs should be developed for the learners to nurture both problem-solving skills and creative thinking skills to derive the solutions right for themselves to resolve various complicated problems that occur in the real world.

\subsection{Creative Problem Solving (CPS) Model}

Creative problem-solving is defined as the process of discovering problems through repetitive thinking process including divergent thinking and convergent thinking to resolve certain problems and searching for relevant resources to state the specific problems, generate ideas, and create new useful solutions [4]. The Creative problem solving (CPS) model is the most popular model which has been used to improve creative problem-solving skills. The CPS mode guides the bverall process to solve problems creatively. Isaksen and Treffinger [9] suggestecthe six steps of CPS (configuration of opportunities, discovery of resources, statement of problems, discovery of ideas, discovery of solutions, and construction of aceeptance foundation) while emphasizing the dynamic balance of divergent thinking and convergent thinking which are not considered much with the existing (PS) models. For this study, researchers developed CPS model based on the CPS model of Isaksen and Treffinger [9] and CPS teaching and learning model developed by Moon [3], Figure 1 shows CPS model that we developed.

\begin{tabular}{|c|c|}
\hline CPS Stage & Teaching and Learning Activity \\
\hline $\begin{array}{l}\text { 1. Discovery of } \\
\text { Opportunities }\end{array}$ & $\begin{array}{l}\text { 1) Understanding the problem situation } \\
\text { 2) Creating the opportunity for problem-solving } \\
\text { 3) Selecting the key opportunity for problem-solving (area } \\
\text { of interest) }\end{array}$ \\
\hline $\begin{array}{l}\text { 2. Exploration } \\
\text { of Resources }\end{array}$ & $\begin{array}{l}\text { 4) Searching for the related information } \\
\text { 5) Selecting and evaluating related information }\end{array}$ \\
\hline $\begin{array}{l}\text { 3. Statement of } \\
\text { Problems }\end{array}$ & $\begin{array}{l}\text { 6) Guiding how to state the problems } \\
\text { 7) Stating various problems } \\
\text { 8) Selecting the key problems }\end{array}$ \\
\hline $\begin{array}{l}\text { 4. Discovery of } \\
\text { Ideas }\end{array}$ & $\begin{array}{l}\text { 9) Creating ideas for problem-solving } \\
\text { 10) Elaborating ideas }\end{array}$ \\
\hline $\begin{array}{l}\text { 5. Development } \\
\text { of Solution }\end{array}$ & $\begin{array}{l}\text { 11) Creating the evaluation criteria for solution } \\
\text { 12) Selecting the evaluation criteria for solution } \\
\text { 13) Selecting the final solution }\end{array}$ \\
\hline
\end{tabular}




\section{Acceptance Foundation}

14) Planning for final solution

15) Elaborating the action plan for final solution

※ Source: [4] J. Kim, Y. Kim, J. Do and S. Heo, "Development of CS Couse for Improving Creativity based on CPS Model: Focusing on image-making", ASEHL, vol. 9, (2016), pp. 97-101.

\section{Methodology}

The purpose of this study is to develop a CS course that is based on the CPS model to develop college students' creativity and upright character. To achieve the purpose of this study, we identified the development process of CS course. Figure 2 shows the development process which was developed based ADDIE model, which is the most popular instructional design model [14].

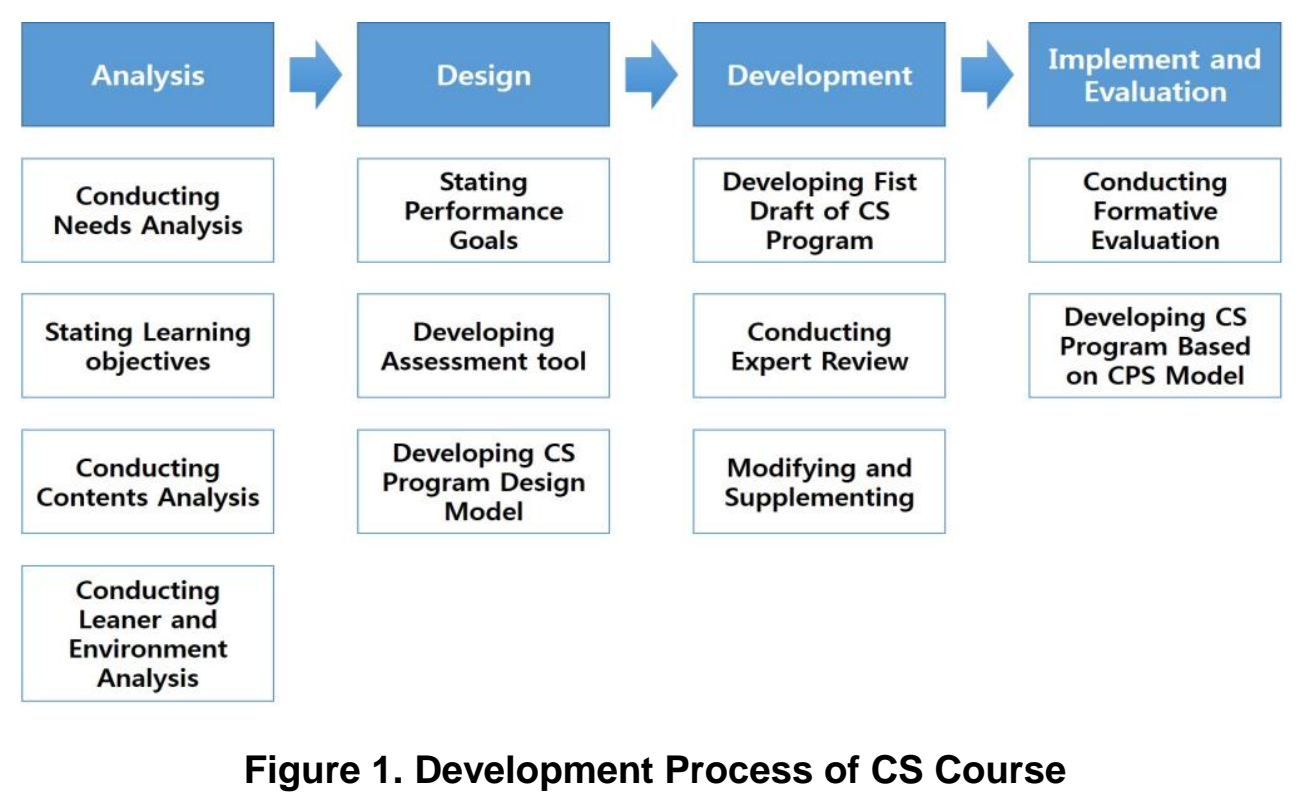

※ Source: [4] J. Kim, Q. Kim, J. Do and S. Heo, "Development of CS Couse for Improving Creativity baseg on CPS Model: Focusing on image-making", ASEHL, vol. 9, (2016), pp. 97-101.

In the analysis stage, first, the foundation for the development of a CS program was laid with the CPS model for college students' creativity and upright character by analyzing the situations of the current CS programs and the CS training activities demanded by the educational sector. Second, it stated the information which learners wish to achieve and the teaching objectives that result from the training after the program. Third, the subsequent functions were analyzed to achieve the teaching objectives. It determined the knowledge, skills, and attitude required to illustrate the sequence of learning and learning in the program. Fourth, it analyzed the learners and the learning situations.

In the design stage, first, the performance objective on what learners can do after learning based on the results of teaching analysis, learners, and situational analysis is stated. Second, it developed an assessment tool that can measure whether learners have achieved the objective. Third, it conducted a literature analysis of the CPS model to establish the teaching strategies. As a result, it derives the major process, stages, and teaching-learning activities of CPS model and developed 'a CS teaching model that applies the CPS model.' 
In the development stage, first, the program draft was developed based on the CS teaching model with the CPS model developed in the previous stage. Second, the draft of program was evaluated by an expert group of two instructors teaching classes using creative problem-solving (CPS) and one image-making expert. Third, it modified and supplemented the course based on the results of expert evaluation.

In the implementation and evaluation stage, first, the modified course was applied to formative evaluation on a small group of 10 college students attending $\mathrm{K}$ College in Incheon. Second, the course was modified and supplemented based on the results of formative evaluation to complete the CS course that applies the final CPS model.

\section{Results}

\subsection{CS Course Overview}

The course information of developed CS course based on CPS model is as follow.

Table 2. CS Course Overview

\begin{tabular}{|c|c|}
\hline Course Topic & Image-making for gettir \\
\hline $\begin{array}{c}\text { Instructional } \\
\text { Objectives }\end{array}$ & $\begin{array}{l}\text { Students are able to } \\
\text { job they want. }\end{array}$ \\
\hline $\begin{array}{c}\text { Contents of } \\
\text { Each Module }\end{array}$ & $\begin{array}{l}\text { Session 1: The components of image-making } \\
\text { Session 2: The factors mecessary for image-making } \\
\text { Session 3. Establishing the plan for image-making }\end{array}$ \\
\hline $\begin{array}{c}\text { CPS activity of } \\
\text { Each Module }\end{array}$ & $\begin{array}{l}\text { Session 1: Discoveryef Opportunities, Exploration of } \\
\text { Resources } \\
\text { Session 2: Statement of Problems, Discovery of Ideas } \\
\text { Session 3: Pevelopment of Solution, Acceptance } \\
\text { Boundation }\end{array}$ \\
\hline
\end{tabular}

The content of the firstsession is learning the components of image-making. The components of image-naking are learned preliminarily for image-making for job-finding. Based on this, learners should contemplate the components of image-making which they should challenge and select the factors they deem important. The CPS stages that apply to the first session are the first stage for the discovery of opportunities and the second stage for the sêarch of resources. Learners should have the opportunities to find the image components they should challenge for image-making suitable for the jobs they want to have and derive the key factors. For this purpose, they should first analyze the images the ompanies want and create the albums of images. Next, they compare the key factors of nnage they select and the results of resources to prepare the worksheet that compares what is common and what is different.

The content of the second session is selecting the factors necessary for my own imagemaking. The CPS stages applied to the second session are the third stage for the statement of problems and the fourth stage for the discovery of ideas. Learners are asked to prepare various derived problems using the bulletin board and select two image-making factors they are required to have. In this stage, learners can clarify the framework of problems they need to resolve and generate the ideas to suggest the solution. Learners share information with other learners who have similar problems through discussions to 
generate a broad range of ideas. By doing so, they can finally derive the factors they need for their own image-making.

The content of the third session is establishing the plan for image-making. Specific plans are established to satisfy the elements required for their own image-making. The CPS stages applied to the third session include the fifth stage for deriving the solution and the sixth stage for building the acceptance foundation. Specific strategies for executing the image-making are prepared and evaluated by instructors and fellow learners for feedback.

\subsection{Statement of Performance Objectives in Each Session}

The objectives for each session to achieve the teaching objectives for image-making required for learners' job-finding are as follows:

Table 3. Performance Objectives in Each Session

\begin{tabular}{|c|c|}
\hline Session & Objectives \\
\hline $\begin{array}{l}\text { 1. The } \\
\text { components of } \\
\text { image-making }\end{array}$ & $\begin{array}{l}\text { - Students are able to list the components of image- } \\
\text { making. } \\
\text { - Students are able to explain the image-making } \\
\text { components most important for finding the right job. } \\
\text { - Students are able to talk about the image of manpower } \\
\text { pursued by one's desired company }\end{array}$ \\
\hline $\begin{array}{l}\text { 2. The factors } \\
\text { necessary for } \\
\text { image-making }\end{array}$ & $\begin{array}{l}\text { - Students are able to set the image-making factors one } \\
\text { needs to find the job he/she yants. } \\
\text { - Students are able to derive ideas for problem-solving } \\
\text { through discussion. } \\
\text { - Students are able to draw a mind map for my } \\
\text { successfulinage-making. }\end{array}$ \\
\hline $\begin{array}{l}\text { 3. Establishing } \\
\text { the plan for } \\
\text { image-making }\end{array}$ & $\begin{array}{l}\text { Students are able to decide the final image-making } \\
\text { method according to the selected standards. } \\
\text { - Students are able to establish the plans for my own } \\
\text { image-making. }\end{array}$ \\
\hline
\end{tabular}

\subsection{Development of Draft of CS Course with the CPS Model}

In the image-rnakng course of a CS program, the teaching objective is to improve college students image-making to be able to have develop image many companies demand. A universal image-making program was applied to the CPS model to develop according to a systemized teaching approach. A new program of three sessions was developedaccording to the stages of CPS and each session took two hours.

\subsection{Results of Expert Review}

The results of expert review of the draft of CS program that applied the CPS model showed an average of 4.2 points (out of 5 points). The results for each item of expert review are as follows: feasibility of achievement of teaching objectives (4.0 points), feasibility of content of each session (4.6 points), feasibility of teaching-learning activities (4.3 points), expressiveness of program (4.0 points), and attainability in classes (4.3 points). Based on the responses to open-end questions on what the program needs for overall improvement, it implied that it 'needs various creative thinking methods and specific guidelines for teaching/learning activities.' The draft of CS program that applied the CPS model was modified and supplemented based on this implication. 


\subsection{Results of Formative Evaluation}

The results of formative evaluation of a small group on the CS program that applies the CPS model that was modified based on the results of expert review showed an average of 3.8 points (out of 5 points). The achievement of course objectives through learners' interests and final assignment in the program was 3.9 points. As a result of an open-end question on the improvement of program, the instructor's messages were adjusted to provide learners with enough activity time considering the opinion that 'there is not much activity time because the program has too much content' and that 'comprehension is limited because the course provides not enough examples.' The program was modified and supplemented with specific guide and additional examples for in-class activities.

\subsection{Final Development of CS Program with the CPS Model}

The program was modified and supplemented based on the results of expert review and formative evaluation and the following final CS program was developed based on the CPS model:

Table 5. Developed CS Program with the CPS Model

\begin{tabular}{|c|c|c|c|}
\hline Stage & Teaching Activity & Studen Activity & Teaching Tool \\
\hline $\begin{array}{l}\text { Discovery } \\
\text { of } \\
\text { Opportuni } \\
\text { ties }\end{array}$ & $\begin{array}{l}\text { 1) Understanding the } \\
\text { problem situation. } \\
\text { Cearners are guided to } \\
\text { problems to resolve for } \\
\text { image-making. } \\
\text { - What is the image } \\
\text { component which I } \\
\text { should challenge for the } \\
\text { right image-making for } \\
\text { the job I want? }\end{array}$ & $\begin{array}{l}\text { discuss the images that } \\
\text { come to their mind with } \\
\text { the instructor's question. } \\
\text { components of image- } \\
\text { making and understand } \\
\text { the concept of each } \\
\text { factor. }\end{array}$ & $\begin{array}{l}\text { Individual } \\
\text { worksheets } \\
\text { "Image-making } \\
\text { challenge for } \\
\text { my change!" }\end{array}$ \\
\hline
\end{tabular}




\begin{tabular}{|c|c|c|c|}
\hline & $\begin{array}{l}\text { 2) Creating the } \\
\text { opportunity for } \\
\text { problem-solving } \\
\text { - What is the image } \\
\text { factor which I should } \\
\text { change most urgently or } \\
\text { seriously among the } \\
\text { components listed? }\end{array}$ & $\begin{array}{l}\text { - Learners select two } \\
\text { most important factors } \\
\text { among the image-making } \\
\text { factors they have } \\
\text { derived. }\end{array}$ & \\
\hline & $\begin{array}{l}\text { 3) Selecting the key } \\
\text { opportunity for } \\
\text { problem-solving (area } \\
\text { of interest) } \\
\text { - Learners are guided to } \\
\text { derive their areas of } \\
\text { interests and key } \\
\text { opportunities among the } \\
\text { factors listed. }\end{array}$ & & \\
\hline \multirow[t]{2}{*}{$\begin{array}{l}\text { Explorati } \\
\text { on of } \\
\text { Resources }\end{array}$} & $\begin{array}{l}\text { 4) Searching for the } \\
\text { related information } \\
\text { - Learners are guided to } \\
\text { search the resources on } \\
\text { the images companies } \\
\text { want. }\end{array}$ & $\begin{array}{l}\text { - Learners search for the } \\
\text { resources related to the } \\
\text { image pursued by their } \\
\text { desired companres. }\end{array}$ & e. \\
\hline & $\begin{array}{l}\text { 5) Selecting and } \\
\text { evaluating related } \\
\text { information } \\
\text { - Learner select and } \\
\text { evaluate the resources } \\
\text { suttable for the key } \\
\text { problem-solving } \\
\text { opportunities (areas of } \\
\text { interest) they have } \\
\text { selected. }\end{array}$ & $\begin{array}{l}\text { Learners evaluate and } \\
\text { select the resources } \\
\text { suitable for the key } \\
\text { problem-solving } \\
\text { opportunities (areas of } \\
\text { interest) among the } \\
\text { various resources. }\end{array}$ & \\
\hline \multirow[t]{2}{*}{$\begin{array}{l}\text { Statement } \\
\text { of } \\
\text { Problems }\end{array}$} & $\begin{array}{l}\text { 6) Guiding how to state } \\
\text { the problems } \\
\text { - Learners are guided to } \\
\text { state the specific } \\
\text { problems. }\end{array}$ & & \multirow[t]{2}{*}{$\begin{array}{l}\text { Making the } \\
\text { problem bulletin } \\
\text { board. }\end{array}$} \\
\hline & $\begin{array}{l}\text { 7) Stating various } \\
\text { problems } \\
\text { " "How should I make an } \\
\text { image to join that } \\
\text { company?" }\end{array}$ & & \\
\hline
\end{tabular}




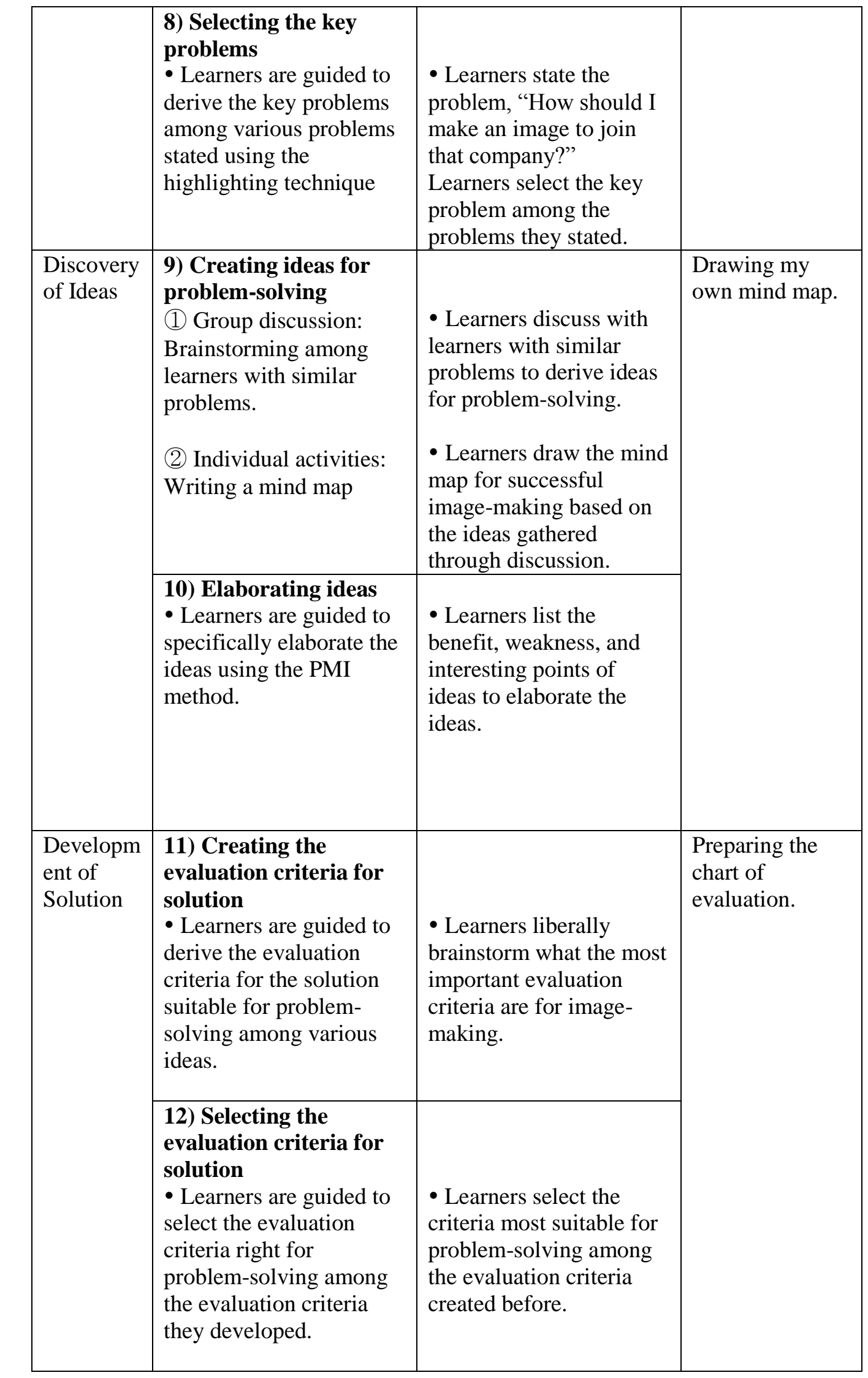




\begin{tabular}{|c|c|c|c|}
\hline & $\begin{array}{l}\text { 13) Selecting the final } \\
\text { solution } \\
\text { - Learners are guided to } \\
\text { select the final solution } \\
\text { using the evaluation } \\
\text { chart based on the } \\
\text { evaluation criteria. }\end{array}$ & $\begin{array}{l}\text { - Learners use the } \\
\text { evaluation chart to select } \\
\text { the final image-making } \\
\text { method (final solution). }\end{array}$ & \\
\hline \multirow[t]{2}{*}{$\begin{array}{l}\text { Acceptan } \\
\text { ce } \\
\text { Foundatio } \\
\mathrm{n}\end{array}$} & $\begin{array}{l}\text { 14) Planning for final } \\
\text { solution } \\
\text { - Learners are guided to } \\
\text { establish the action plan } \\
\text { for helpers, resisters, and } \\
\text { potential action plans. }\end{array}$ & $\begin{array}{l}\text { - Learners plan image- } \\
\text { making suitable for their } \\
\text { areas of job-finding. }\end{array}$ & \multirow[t]{2}{*}{$\begin{array}{l}\text { Writing the } \\
\text { image-making } \\
\text { action plan. }\end{array}$} \\
\hline & $\begin{array}{l}\text { 15) Elaborating the } \\
\text { action plan for final } \\
\text { solution } \\
\text { - Learners are guided to } \\
\text { create the action } \\
\text { strategies to specify the } \\
\text { plan and present their } \\
\text { determination } \\
\text { individually. }\end{array}$ & $\begin{array}{l}\text { - Learners prepare } \\
\text { specific strategies for the } \\
\text { finally selected image } \\
\text { making action plan. } \\
\text { - Learners presentand } \\
\text { Share the image-nraking }\end{array}$ & \\
\hline
\end{tabular}

This study developed a CS course by applying the CPS model in order to improve college students' creativity and upright character. In the developed CS course, learners will demonstrate convergent and critical thinking skills in the process of generating and evaluating problem-solving ideas for successful job-finding. Developed CS course made efforts to develop students' creatrvity by developing and applying several design strategies. First, his program discusses topics that are interesting for learners, but difficult to resolve in relation to themselves. Therefore, its biggest strength is that a liberal atmosphere can be created using the free association and heat methods for learners to generate creative ideas in the first stage of CPS model for the development of opportunities. Second, learners should be able to configure the framework of problems they need to resolve. To assist these activities, this study applied the highlighting method and provided a personal problem-solving bulletin board to students to expand their thinking Thurd, from the literature review on existing studies about CPS model, most learners find it most difficult to develop the selection criteria to develop the solution in the CPS stages [13]. Therefore, this study used free association method for learners' divergent thinking that was required to generate evaluation criteria to supplement the problems for learners to think about the major selection criteria that affect image-making. Learners can use the evaluation chart to promote convergent thinking when the final solution is selected.

The characteristic of this study is that it developed a course for the CS training by integrating the CPS model for developing learners' creativity. It is an optimized course for nurturing learners' creativity and upright character. With this characteristic, the significances of developed CS course are as follow: first, it will improve the creativity of college students who have participated in a CS course that applies the CPS model. Second, it can help professors teaching CS course in colleges teach image-making course based on the CPS model in schools. Third, it is expected to suggest study directions for 
the development of other CS courses in addition to image-making. In the future, a study is required to analyze the effect of developed CS course applying the CPS model in the real classroom environments.

\section{References}

[1] R. Collins, "The Credential society: an historical sociology of education and stratification", Academic Press, New York, (1979).

[2] S. H. Heo, Y. Y. Kim, J. Y. Kim, J. S. Kim and J. H. Song, "Creative thinking and Problem solving for developing NCS vocational basic skills", Academia Press, Seoul, (2015).

[3] Y. M. Mun, "Development and Application of CPS Model into the Instruction of Geography for Creativity Enhancement", Journal of the association of Korean geographers, vol. 2, no. 2, (2013), pp. 123-136.

[4] Y. Kim, K. J. Do and S. Heo, "Development of CS Couse for Improving Creativity based on CPS Model: Focusing on image-making”, ASEHL, vol. 9, (2016), pp. 97-101.

[5] C. L. Lim, S. K. Yun, K. S. Park and M. Y. Hong, "A Study of an Integrated Instructional Model in a Collegiate Course for Creative Problem Solving with Online Support System", Journal of Educational Technology., vol. 25, no. 1, (2009), pp. 171-203.

[6] J. Y. Kim and J. H. Choi, "Customer Satisfaction 1", Academia Press, Seoul, (2008).

[7] M. S. Kim, S. D. Choi and K. W. Kim, "Children's Creative Thinking Process and Products: Strategies and Solutions of an Anti-cafe Problem", The Korean Journal of Thinking Development., vol. 9, no. 2, (2013), pp.99-117.

[8] K. R. Min, "Analysis the influence about the reasons why the CS education Improve the job satisfactions: mainly about ' $\mathrm{K}$ ' public institutions", Unpublished master's thesis, (2012).

[9] S. G. Isaksen and D. J. Treffinger, "Creative Problem Solying: The basic course", Bearly Ltd, New York, (1985).

[10] Japan Management Association, "A Case Study of Knowledge Management for CS", Book21, Seoul, (1993).

[11] J. Y. Kim, "Customer Satisfaction for improvement of NCS vocational basic skills", Academia Press, Seoul, (2014).

[12] J. S. Kim, "A Study on Moral Education for Development of Higher-Order Thinking", Unpublished doctorate's thesis, (2011).

[13] J. Y. Lee, Y. M. Koo, S. U. Jin, J.H Seo and B. S. Go, "Analysis of the Effectiveness of Creative Problem Solving Model-Based Instruction in Primary School Social Studies: Focus on Effect on Students' Creative Problem Solving Skils and Learning Achievement", Journal of Educational Technology, vol. 23, no. 2. (2007), pp. 105-133.

[14] Wikipedia. ADDIE Model. from https://en.wikipedia org/w/index.php?title=ADDIE_Model\&oldid=737848331, (2016).

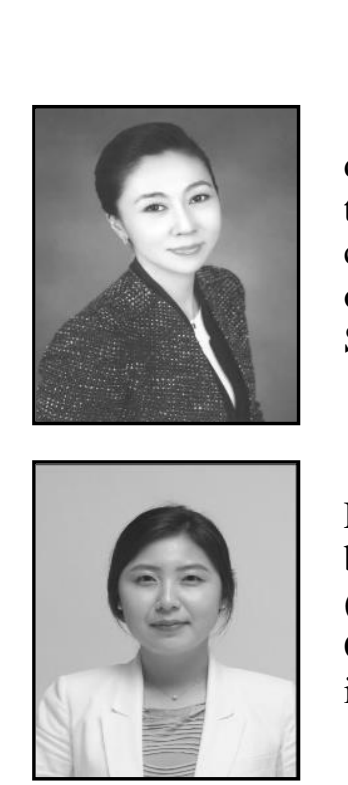

\section{Authors}

Jooyoung Kim, She is a director of Korea NCS research and development institute. She received her Ph.D. degree in educational technology. She has been teaching customer satisfaction and communication skills at the university, and published several books on those topics. Her research interests are National Competency Standards(NCS), vocational education, and customer satisfaction.

Yunyoung Kim, She is a doctoral candidate in the Department of Educational Technology at Andong National University. She has been teaching educational technology, creative problem solving (CPS), life-long education at the university, and published a book on CPS. Her research interests are creative problem solving, instructional design, flipped learning. 

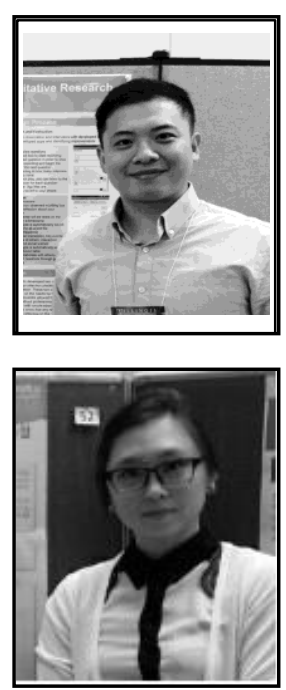

Jaewoo Do, $\mathrm{He}$ is a doctoral candidate in the Educational Psychology and Counseling Department at the University of Tennessee. He has designed and developed the curriculums and online courses for companies, universities, and Korean government institutions as an instructional designer. His research interests are online course design, online learning environment, design thinking and NCS.

Sohyeon Heo, She is a doctoral candidate in the educational technology Department at the Andong National University. She has been teaching educational technology and creative problem solving(CPS) at the university and published a book on CPS. Her research interests are systemic instructional design, academic emotional regulation and CPS. 